\title{
Development of a core outcome set based on Case Report Form (CRF) to assess laboratory biomarkers and clinical parameters in Onco-Hematology area
}

\author{
Mariangela Vanalli ${ }^{1 *}$, Francesca Rio ${ }^{2}$ \\ From The 4th Meeting of the Core Outcome Measures in Effectiveness Trials (COMET) Initiative \\ Rome, Italy. 19-20 November 2014
}

\section{Background}

The number of cases, the crude and age-standardized incidence, mortality rates and the prevalence proportions estimated by the Italian Association of Cancer Registries (AIRTUM) presently providing the epidemiological indicators for the major cancers used in ICD-O3.1 [1-3]. By 2012, the breast cancer incidence in women (age $25 \pm$ over 85 years) was about $29 \%$; trends for stomach and colorectal cancer were about $5 \%$ and $14 \%$ for both genders (age $35 / 45 \pm$ over 85 years); the lung cancer incidence rates was about $15 \%$ in men (age $45 \pm$ over 85 years) and $6 \%$ in women (age $40 \pm$ over 85 ) in $2009[4,5]$. From 2011 onwards the tendency changed: the female rates $(20$ per 100,000$)$ increased much more rapidly than the male rates [6].

Aim of this study is to examine the relationships among the incidence of genera-cancer-associated risk factors and routine laboratory in cancer patients through CRF.

\section{Materials and Methods}

The CRF database has been developed by a dedicated working group using Delphi process. It contain anonymous records on patient characteristics (gender, age, alcohol and smoking history, height, body weight, performance status measured using the Eastern Cooperative Oncology Group-ECOG PS, chronic comorbidities weighted by the Charlson Comorbidity Index-CCI, type and stage of tumor) (Figure 1) [7-9] and one set of

\footnotetext{
* Correspondence: mariangela.vanalli@libero.it

'Department of Immunohematology and Transfusion Medicine, Hospital

Papa Giovanni XXIII, Bergamo, Italy

Full list of author information is available at the end of the article
}

biomarker laboratory data identified in several variables (Table 1) $[10,11]$.

\section{Results}

Between 2012 and 2014, 1373 cancer patients were enrolled at three Italian Oncological Institutions after informed consent. Among these patients, 36\% were men and $64 \%$ were women (mean age $71 \pm 45$ years) (Figure 2 ) and breast was the most frequent type cancer (43\%) followed by lung $(29 \%)$, colon-rectum $(18 \%)$ and stomach (9\%). $72 \%(n=85)$ of the lung, $67 \%(n=24)$ of the stomach, $33 \%(n=25)$ of the colon-rectum, $4 \%(n=7)$ of the breast cancer patients had comorbidities weighted with 3 point and above (Age Unadjusted Charlson-ComorbidityIndex $\geq 4 ; \mathrm{HR}=6.38$; 99\% CI $[3.07,13.24]$ ) $[12,13]$ (Figure 3). Multivariate analysis determined that comorbidity was highly associated with cancer type, stage and ECOG PS $(\mathrm{p}=0.01)$ (Figure 4). Evaluation between cardiovascular

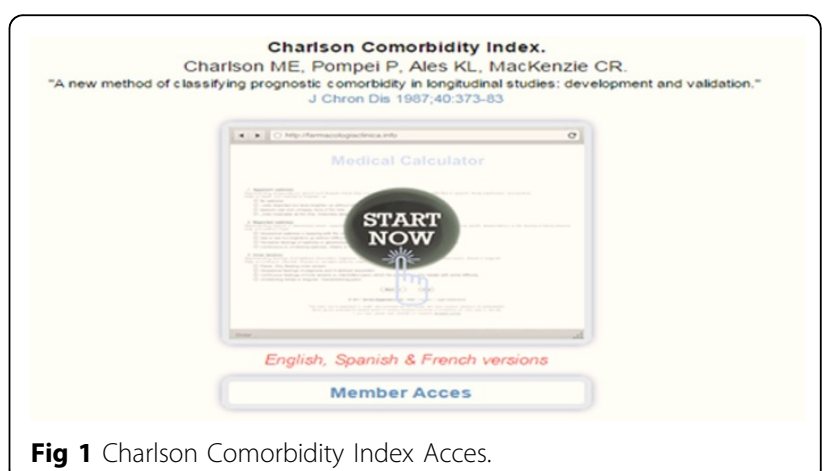

Fig 1 Charlson Comorbidity Index Acces. 
Table 1. Multivariate Analyses of cancer type, comorbidity score and biomarkers laboratory

\begin{tabular}{lcccc}
\hline Comorbidity & $\begin{array}{c}\text { Breast } \\
\mathbf{p}\end{array}$ & $\begin{array}{c}\text { Colon-rectum } \\
\mathbf{p}\end{array}$ & $\begin{array}{c}\text { Stomach } \\
\mathbf{p}\end{array}$ & $\begin{array}{c}\text { Lung } \\
\mathbf{p}\end{array}$ \\
\hline HCT_cod & 0.105 & 0.708 & 0.387 & 0.078 \\
Hb_cod & 0.035 & 0.775 & 0.466 & 0.351 \\
RBC_cod & 0.564 & 0.343 & 0.194 & 0.448 \\
WBC_cod & 0.292 & 0.172 & 0.930 & 0.583 \\
PLT_cod & 0.167 & 0.535 & 0.401 & 0.332 \\
\hline CCI_SCORE $\geq \mathbf{4}$ & $\mathbf{0 . 4 9 5}$ & $\mathbf{0 . 0 2 9}$ & $\mathbf{0 . 0 9 2}$ & $\mathbf{0 . 3 8 1}$
\end{tabular}

cancer type: breast, colon-rectum, stomach and lung; biomarkers laboratory: $\mathrm{HCT}, \mathrm{Hb}, \mathrm{RBC}, \mathrm{WBC}, \mathrm{PLT}$;

\section{Correction \\ 1. Corrected $7 / 2014$ (based on 1996 paper) \\ 2. Age-based scoring starts at age 50 years (not age 40 years) Scoring \\ 1. Age $<50$ years: 0 points \\ 2. Age $50-59$ years: 1 points \\ 3. Age $60-69$ years: 2 points \\ 4. Age $70-79$ years: 3 points}

Fig $2 \mathrm{CCl}$ and their respective point scores. disease, risk of bleeding, deep-vein thrombosis and colonrectum cancer stage $(\mathrm{p}=0.01)$, breast $(\mathrm{p}=0.03)$, lung $(\mathrm{p}=0.01)$ compared into comorbidities (Figure 5). The other tested variables: Hgb level, neutrophil and platelet counthad had the strongest relationship with breast, lung cancer stage $(\mathrm{p}=0.02)$, stomach $(\mathrm{p}=0.002)$ and colonrectum $(\mathrm{p}=0.1)[14,15]$.

\section{Conclusions}

The appropriateness of results could be useful to better describe the role of CRF and biomarkers recorded in patient charts as well as the other variables could allow nurses to identify patients at risk for shorter survival time following hospitalization $[16,17]$.

\section{Acknowledgments}

This study was conducted with three Italian Oncological Institutions funded by Cancer Research in Bergamo, Milan and Rome. The author would like to thank General Directors and Nurse Directors of these Hospitals for authorizing the study; patients, nursing coordinators, nurses working in Onco-Hematology area for their hospitality and support in data collection process and for their assistance in patient recruitment.

\section{Authors' details}

'Department of Immunohematology and Transfusion Medicine, Hospital Papa Giovanni XXIII, Bergamo, Italy. ${ }^{2}$ University of Milan Bicocca, Milan, Italy.

Published: 29 May 2015

\begin{tabular}{|l|l|l|l|l|}
\hline Points & $\mathbf{1}$ & $\mathbf{2}$ & $\mathbf{3}$ & $\mathbf{6}$ \\
\hline Morbidity & MI & Hemiplegia & Moderate-severe liver disease & Metastatic solid tumour \\
& CCF & Moderate-severe & & AIDS \\
& PVD & CRF & & \\
& COPD (with end-organ damage) & & \\
& DM (without end-organ damage) & Malignancy & & \\
& Cerebrovascular disease & Leukaemia & & \\
& Lementia & & & \\
& Ulcers & & \\
& Connective tissue disease & & & \\
& Mild liver disease & & & \\
\hline
\end{tabular}

Abbreviations: MI, myocardial infarction; CCF, congestive cardiac failure; PVD, peripheral vascular disease; COPD, chronic obstructive pulmonary disease; DM, diabetes mellitus; CRF, chronic renal failure.

Fig $3 \mathrm{CCl}$ and their respective point scores

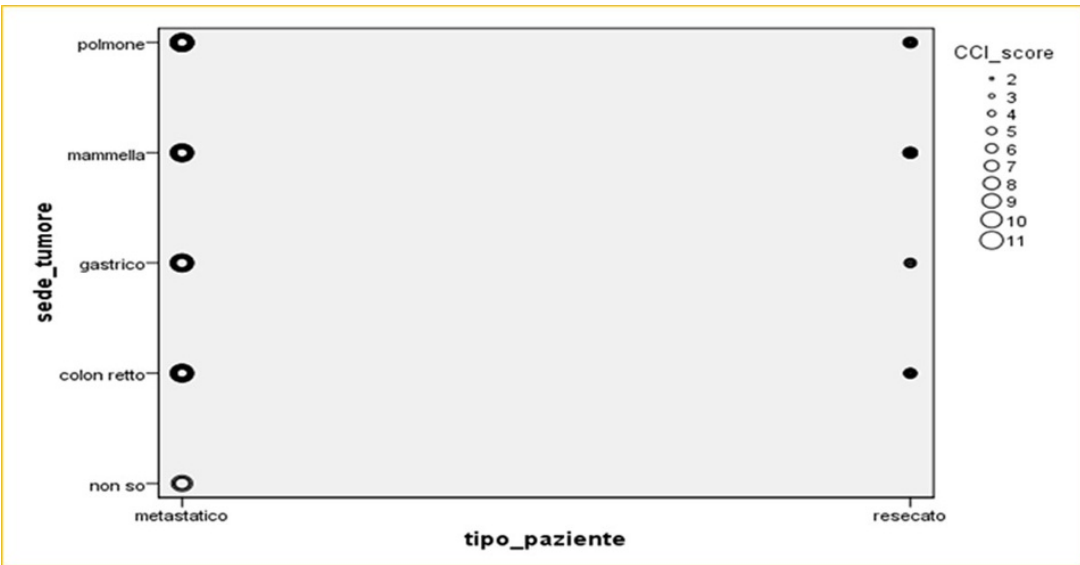

Fig 4 Multivariate Analysis and the comorbidities of CCI with IBM SPSS Italian version 21 statistical software. 


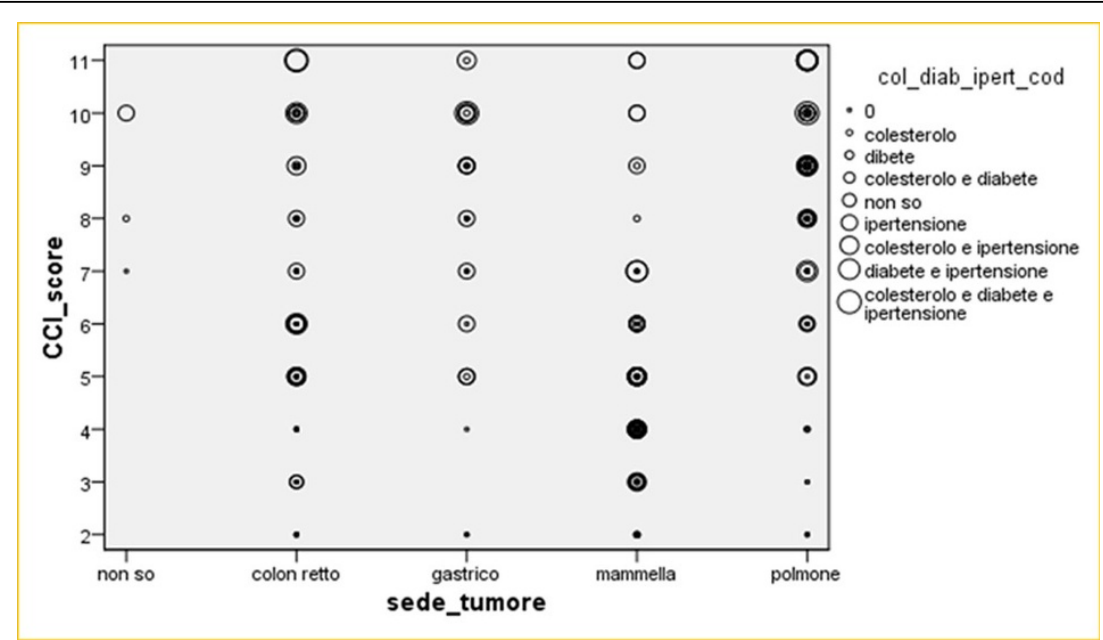

Fig 5 Multivariate Analysis and the comorbidities of CCI with IBM SPSS Italian version 21 statistical software.

\section{References}

1. Abbasi S, Badheeb A: Prognostic factors in advanced non-small-cell lung cancer patients: Patient characteristics and type of chemotherapy. Lung Cancer International 2011, 0(0):1-4.

2. Albain KS, Crowley JJ, LeBlanc M, Livingston RB: Survival determinants in extensive-stage non-small-cell lung cancer: The Southwest Oncology Group experience. Journal of Clinical Oncology 1991, 9:1618-1626.

3. American Cancer Society: Cancer facts and figures. 2012, Retrieved from [http://www.cancer.org/acs/groups/content/@epidemiologysurveilance/ documents/document/acspc-031941.pdf]. Accessed November 21, 2014.

4. Boyd CM, Vollenweider D, Puhan MA: Informing evidence-based decisionmaking for patients with comorbidity: availability of necessary information in clinical trials for chronic diseases. PLOS ONE 2012, 7: e41601.

5. Charlson ME, Pompei P, Ales KL, Mackenzie CR: A new method of classifying prognostic comorbidity in longitudinal studies: Development and validation. J Chronic Dis 1987, 40(5):373-383.

6. Corbett J: Laboratory tests and diagnostic procedures with nursing diagnoses. 7 edition. Upper Saddle River, NJ: Pearson/Prentice Hall; 2008

7. Cox D, Oakes D: Analysis of survival data London, England: Chapman and Hall; 1984.

8. Foucher ES, O'Callaghan M, Ferlay J, Masuyer E, Rosso S, Forman D, Bray F, Comber $\mathrm{H}$ : The European Cancer Observatory: A new data resource. European Journal of Cancer 2014, 0(0):1-13.

9. Gatta G, Ciampichini R, Bisanti L, Contiero P, Tessandori R, Baili P, Rossi S: Estimates of cancer burden in Lombardy. Tumori 2013, 99(3):277-84.

10. Grande E, Inghelmann R, Francisci S, Verdecchia A, Micheli A, Baili P, Capocaccia R, De Angelis R: Regional estimates of all cancer malignancies in Italy. Tumori 2007, 93:345-351.

11. Jemal A, Siegel R, Ward E, Hao Y, Xu J, Thun MJ: Cancer statistics. A Cancer Journal for Clinicians 2009, 59(4):225-249.

12. International Agency for Research on Cancer: Cancer Incidence in Five Continents Annual Dataset. 2014 [http://ci5.iarc.fr/Cl5plus/ci5plus.htm], Accessed November 21.

13. Luo J, Chen YJ, Narsavage GL, Ducatman A: Predictors of Survival in Patients with Non-Small Cell Lung Cancer. Oncology Nursing Forum 2012, 39(6):609-16.

14. Oken MM, Creech RH, Tormey DC, Horton J, Davis TE, Mc-fadden ET, Carbone PP: Toxicity and response criteria of the Eastern Cooperative Oncology Group. American Journal of Clinical Oncology 1982, 5(6):649-655.

15. Quan H, Li B, Couris CM, Fushimi K, Graham P, Hider P, Januel JM, Sundararajan V: Updating and validating the Charlson comorbidity index and score for risk adjustment in hospital discharge abstracts using data from 6 countries. Am J Epidemiol 2011, 173:676-82.

16. Radovanovic D, Seifert B, Urban P, Eberli FR, Rickli H, Bertel O, Puhan MA, Erne P: Validity of Charlson Comorbidity Index in patients hospitalised with acute coronary syndrome. Insights from the nationwide AMIS Plus registry 2002-2012. Heart 2014, 100(4):288-94, [ClinicalTrials.gov Identifier NCT01305785]

17. Yurkovich M, Zubieta JAA, Thomas J, Gorenchtein M, Lacaille D: A systematic review identifies valid comorbidity indices derived from administrative health data. Journal of Clinical Epidemiology 2015, 68:3-14.

doi:10.1186/1745-6215-16-S1-P23

Cite this article as: Vanalli and Rio: Development of a core outcome set based on Case Report Form (CRF) to assess laboratory biomarkers and clinical parameters in Onco-Hematology area. Trials 2015 16(Suppl 1):P23.

\section{Submit your next manuscript to BioMed Central and take full advantage of:}

- Convenient online submission

- Thorough peer review

- No space constraints or color figure charges

- Immediate publication on acceptance

- Inclusion in PubMed, CAS, Scopus and Google Scholar

- Research which is freely available for redistribution 